\title{
Influence of Physical Environment on Customer Satisfaction and Return Intention in Kenyan Rated Restaurants
}

\author{
Margaret N. Githiri ${ }^{1}$ \\ ${ }^{1}$ Department of Natural Resources, Egerton University, Egerton, Kenya \\ Correspondence: Margaret N. Githiri, Department of Natural Resources, Egerton University, P.O. Box \\ 536-20115, Egerton, Kenya. Tel: 254-72-386-8248.
}

Received: September 20, 2016

Accepted: October 13, 2016

Online Published: November 15, 2016

doi:10.20849/ajsss.v2i1.82

URL: http://dx.doi.org/10.20849/ajsss.v2i1.82

\begin{abstract}
The study was conducted to examine the influence of physical environment on customers' satisfaction and return intention. The study involved 345 customers in both Nairobi and Coastal region of Kenya. The sampling technique was simple random. DINESCAPE items were used in measuring physical environment. The instrument for data collection was self administered structural close ended questionnaire. Statistical package for social sciences (SPSS) version 18 was used to analyze the data. Pearson correlation coefficient test indicated a strong positive relationship between physical environment and return intention $(\mathrm{r}=0.605)$ at 0.01 confidence level. A mode of 2 indicated that majority of the respondents were dissatisfied with external appearance of restaurant's environment and the musical background. Results on linear regression analysis revealed a statistical significance between physical environment and customers return intention $(p=0.000)$. This implied that physical environment highly influenced customers' return intention in rated restaurants. To satisfy and encourage most customers to revisit the restaurants, the study suggested that the restaurant managers should device ways of improving the external appearance of the restaurants. They should also offer musical background that is suitable to their type of customers.
\end{abstract}

Keywords: physical environment, return intention, customer satisfaction

\section{Introduction}

\subsection{Background}

Physical environment of restaurants plays a very vital role in customer satisfaction and return intention leading to increase in financial performance in restaurants (Magim and Parker, 2009). Several studies have demonstrated that physical environment plays a role in creating customers; pre- consumption mood before the actual service is delivered. This suggests that physical environment can positively or negatively influence customer's mood (Namasivayam and Mattilla, 2007) which influences quality expectations and impression formation regarding specific consumption experience (Tuzikan and Albayrac, 2016).

A customer visiting a rated restaurant will have pre-conceived expectations regarding physical environment of a rated restaurant. The expectations will be in relation to ambient conditions, spatial layout and functionality; and sign, symbols and artifacts (Bitner, 1992). If the expectations are not met, the customer will be dissatisfied and may not revisit the restaurant again. With easy access to the worldwide web, dissatisfied customers are able to vent their complaints through some medium such as established websites for example Trip advisor.com, Eater.com amongst others. In Kenya these complaints through trip advisor (Mombasa restaurant review, 2016; Nairobi review, 2016) have affected the rate of customer turnover in rated restaurants. Even though various studies have been conducted on the influence restaurant physical environment, there has not been a study conducted on influence of physical environment on rated restaurants in Kenya. Due to the recent rise of both the number of restaurants and the number of people who prefer dinning out, the influence of physical environment on customers in rated restaurants should be investigated. The purpose of this study is therefore is to investigate the influence of physical environment on customers visiting rated restaurant.

\subsection{Relationship between Physical Environment with Customer Satisfaction and Return Intention}

The importance of creating an attractive physical environment has gained growing attention among scholars and hospitality managers as it is a key factor for attracting and satisfying customers in hospitality industry (Han and 
Ryu, 2009). According to Ryu and Jang (2008), physical environment can have a significance impact on perception of the overall quality of the service encounter which in turn affects customer satisfaction in the restaurant industry. Bitner (1990) used the term 'services cape' to describe the manmade physical environment in which the delivery of service products takes place. She identified three dimensions of services cape which influence customer satisfaction and repatronage which are; 1) ambient conditions 2) spatial layout and functionality and 3) signs, symbols and artifacts. Chang (2009) also confirmed that physical environment has a direct indicator of customer satisfaction and return intention

\subsection{Research Hypothesis}

In view of the above results, this study hypothesizes that: Physical environment has a positive influence on customer return intention

\section{Materials and Methods}

\subsection{Study Area}

The study was conducted in Nairobi and Coastal region of Kenya. These areas were selected because they have all the star- rated restaurants in the country (Kenya Gazette, 2003). The two regions also receive the largest number of both domestic and international tourists. Nairobi is the capital and the largest city in Kenya and is ranked fourth out of thirteen cities surveyed in Africa both in terms of visitor number and visitor spend thus highlighting its status as the financial heart of the East African region and a significant African economic hub (United Nations Environmental Programme, 2014).The Coastal region of Kenya is situated immediately south of equator and covers $80,000 \mathrm{~km}$ in south eastern part of Kenya. This region has tourist attractions such as beaches, cultural heritage, marine based habitats amongst others. According to Kenya Tourism Board, $65 \%$ of the tourists coming to Kenya visit the Coastal region making tourism an important part of economy.

\subsection{Target Population and Sample Size}

The study targeted all customers, visiting the rated restaurants. The target population was people who were over eighteen years of age who understood and spoke English.

The sample size of the customers was calculated according to Fisher, Storman and Heaton, (1998) formula which is used in social sciences studies in determining the sample size (Mugenda and Mugenda, 2003).

$$
\mathrm{n}=\frac{\mathrm{Z}^{2} \mathrm{pq}}{\mathrm{d}^{2}}
$$

Where

$\mathrm{n}=$ the desired sample size (if the target population is greater than 10,000)

$\mathrm{z}=$ the standard normal deviate at required confidence level.

$\mathrm{p}=$ the proportion in the target population estimated to have characteristic being measured.

$\mathrm{q}=1-\mathrm{p}$ and $\mathrm{d}=$ the level of statistical significance

$50 \%$ was used as the estimate of the proportion in the target population, as recommended by Fisher et al., (1998). The proportion of the target population was therefore 0.50 ; the $\mathrm{z}$ statistics was 1.96 .

The desired accuracy was 0.05 level, the sample size was as follows:

$$
\mathrm{n}=\frac{(1.96)^{2}(.50)(.50)}{(.05)^{2}}=384
$$

\subsection{Data Collection and Sampling Procedures}

The data collection exercise was undertaken for a period of four months between September 2014 to December 2014. The procedure was done during lunch and dinner as most customers visit restaurants during this time. A token of a biro pen was given to the respondents to encourage them participate in the study.

Simple random sampling technique was employed in sampling the respondents. Every table in the restaurant was allocated a number which was written on pieces of papers. The papers were then put together then handpicked randomly. The customer sitting on the handpicked tables were sampled and given questionnaires to fill. The filled questionnaires were collected by the waiters and handed to the researcher.

The research design adopted was cross sectional survey. This type of study was preferred as it gathers a large scale of data at one point in time and explains phenomenon representing wide population then simply reports what has been found in a variety of ways (Cohen, 2011). 


\subsection{Data Sources}

The data sources included both secondary and primary data. Secondary data was obtained from published journals and books while a self administered questionnaire was used as a tool of obtaining primary data.

\subsubsection{Questionnaire}

The study employed self administered closed ended, five point Likert scale questionnaire comprising of two sections. The first section had seven questions which sought to establish the customer demographic and social economic status. The second section which had nine questions sought to establish the level of satisfaction in relation to physical environment. To be able to measure the level of satisfaction with physical environment, a five point Likert type scale (Geoff, 2010) was used. The scale ranged from very dissatisfied-1, dissatisfied-2, unsure-3, satisfied-4 to very satisfied-5.

\subsection{Data Analysis}

Statistical Package for social sciences (SPSS) version 18 was used in analyzing the data collected. The mean, median and mode were used to measure the level of customer satisfaction. Pearson correlation coefficient analysis was used to assess the relationship between physical environment and return intention of customers. Linear regression was used to predict return intention of customers in relation to physical environment. The collected data was subjected to a reliability analysis (Cronbach's alpha) so as to assess the internal consistency of the set items. The Cronbach alpha of 0.87 revealed that the total scale reliability was very high which indicates that the sample of items performed well in capturing the measured constructs.

\section{Results and Discussions}

\subsection{Customers' Level of Satisfaction with Physical Environment}

Physical environment was measured using the DINES CAPE scale dimensions (Ryu and Jang, 2008) in Table 1. This included external appearance of the restaurant, interior scheme of restaurant, temperature of the dining area, music background, lighting in the dining area, type of linen, type of furnishing, signs of smocking zone area and arrangement of chairs and tables.

Table 1. Customer satisfaction with physical environment

\begin{tabular}{|c|c|c|c|c|c|c|c|c|}
\hline $\begin{array}{l}\text { Physical } \\
\text { Environment }\end{array}$ & & & & & & & & \\
\hline Dimencions & Very Dissatis & Dissatis & Unsure & Satis & V-Satis & & Subtotal & \\
\hline Dimensions & $\mathrm{N} \%$ & $\mathrm{~N} \%$ & $\mathrm{~N} \%$ & $\mathrm{~N} \%$ & $\mathrm{~N} \%$ & mean & median & mode \\
\hline $\begin{array}{l}\text {-External appearance } \\
\text { of the restaurant }\end{array}$ & 13.9 & 33.3 & 4.1 & 30.1 & 18.6 & 3 & 3 & 2 \\
\hline $\begin{array}{l}\text {-Interior scheme of } \\
\text { restaurant }\end{array}$ & 3.8 & 19.7 & 3.8 & 53.3 & 19.4 & 4 & 4 & 4 \\
\hline $\begin{array}{l}\text {-Temperature of the } \\
\text { dining area }\end{array}$ & 3.8 & 30.7 & 2.6 & 47.2 & 15.7 & 3 & 4 & 4 \\
\hline -Music background & 7.0 & 39.1 & 6.7 & 35.7 & 11.6 & 3 & 3 & 2 \\
\hline $\begin{array}{l}\text {-Lighting in the dining } \\
\text { area }\end{array}$ & 2.6 & 26.1 & 4.9 & 53.6 & 12.8 & 3 & 4 & 4 \\
\hline -Type of linen & 6.4 & 31.0 & 9.0 & 44.1 & 9.6 & 3 & 4 & 4 \\
\hline $\begin{array}{l}\text {-Type of furnishing } \\
\text { (seats, tables, etc) }\end{array}$ & 4.6 & 33.0 & 5.8 & 44.1 & 12.5 & 3 & 4 & 4 \\
\hline $\begin{array}{l}\text {-Signs to the smoking } \\
\text { zone area }\end{array}$ & 3.2 & 22.3 & 28.4 & 35.9 & 10.1 & 3 & 3 & 4 \\
\hline $\begin{array}{l}\text {-Arrangement of chairs } \\
\text { and tables }\end{array}$ & 3.8 & 30.7 & 5.5 & 48.1 & 11.9 & 3 & 4 & 4 \\
\hline
\end{tabular}

Mode of 5- very satisfied, 4- satisfied, 3- unsure, 2- dissatisfied and 1- very dissatisfied 
The mode of 2 (Table 1) indicates that most respondents were dissatisfied with the external appearance of the restaurant. The exterior of the restaurant provides the first impression to the customer. Most restaurants especially in Nairobi were located in the city center between old commercial buildings with limited or no parking area. This could have been one reason why the respondents were dissatisfied with the external appearance. According to Omar, Arif and Ahmad (2015), the exterior of the restaurant will not only attract and invite guests to eat, but also influence their experience of the meal. As patrons approach the restaurant, they will scrutinize the exterior in terms of location and parking area which determines the security of the restaurant (Omar et al. 2015). Patrons are also concerned with the attractiveness and upkeep of the exterior of the restaurant in terms of color of the building, windows, curtains, type of entrance and flowers (Jordan and Prinsloo, 2001). A neglected exterior of the restaurant may cause a customer to have a low opinion of the entire operation.

The mode of two in Table 1 also indicated that majority of the respondents were dissatisfied with the musical background. This implies that the music played in the restaurants did not fit or matches with the majority of the respondents' taste causing dissatisfaction. Different respondents have different preference in terms of the kind of music they listen. Respondents who prefer music with slower tempo would be dissatisfied if the background music has a fast tempo and vice versa. This is in agreement with study of Wood and Allen (2012) who found out that music had a significant relationship with customer satisfaction. The respondents were however satisfied with the rest of the dimensions in physical environment.

\subsection{Hypothesis Testing of Physical Environment and Return Intention}

The study employed Pearson correlations coefficient and regression analysis tests in testing the influence of physical environment on customer return intention. According to Hair, Bush and Ortinar, (2002) these tests are the most commonly used techniques in investigating relationships between variables.

\subsubsection{Pearson Correlation Coefficient Test for Physical Environment and Return Intention}

Pearson correlation test sought to find out the relationship between physical environment and customer's return intention.

Table 2. Pearson Correlations Test for physical environment and return intention

\begin{tabular}{|c|c|c|c|c|c|c|}
\hline & & & Coefficier & & & \\
\hline Model & & Unstand & d Coefficients & Standardized & $\mathrm{t}$ & Sig. \\
\hline & & $\beta$ & Std. Error & Beta & & \\
\hline & (Constant) & .759 & .346 & & 2.193 & .029 \\
\hline 1 & $\begin{array}{l}\text { Physical } \\
\text { Environment }\end{array}$ & .262 & .019 & .605 & 14.069 & .000 \\
\hline
\end{tabular}

a. Dependent Variable: Return Intention

**. Correlation is significant at the 0.01 level (2-tailed).

The result (Table 2) shows that there is a positive strong correlation between physical environment and return intention $(\mathrm{r}=0.605, \mathrm{~N}=345, \mathrm{P}=0.000)$ A P- Value of 0.000 is a clear indication that there is a statistical significance between return intention and physical environment at 0.01 confidence level. The results suggest that higher level of physical environment quality were associated with higher level of return intention.

\subsubsection{Regression Analysis}

Linear regression analysis was employed to determine the relationship between return intention and physical environment. 
Figure 1 illustrates the linear relationship between physical environment and return intention.

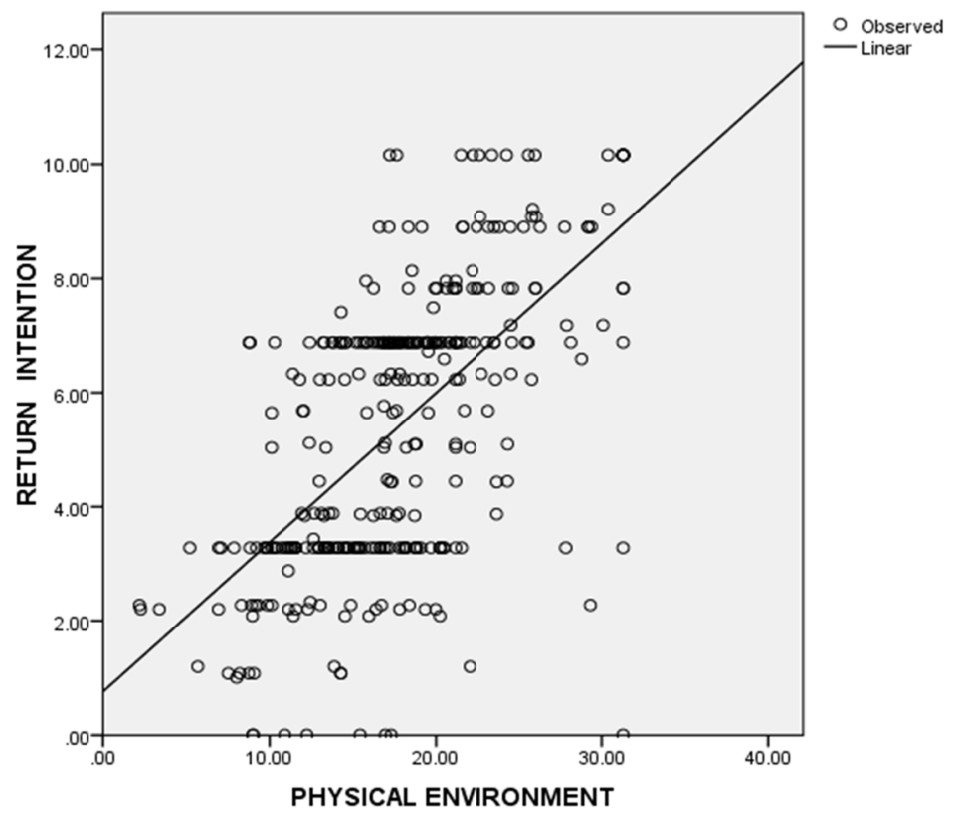

Figure 1. Linear relationship of physical environment and return intention

The scatter plot in Figure 1 indicates a positive linear relationship between physical environment and return intention. Figure 1 also shows that as physical environment increases, there is a corresponding positive increase in customer return intention.

Coefficient of determination test was done because it is a static used in the context of statistical models whose main purpose is to test hypothesis (Agresti and Finlay, 2009). This test shows how well a regression model describes the relationship between dependent and independent variable this is demonstrated by how close the data is to the fitted regression line. Table 3 depicts the Coefficient of determination for physical environment and return intention.

Table 3. Coefficient of determination (Goodness of fit) for physical environment and return intention Model Summary

\begin{tabular}{lcccc}
\hline Model & $\mathrm{R}$ & R Square & $\begin{array}{c}\text { Adjusted R } \\
\text { Square }\end{array}$ & $\begin{array}{c}\text { Std. Error of the } \\
\text { Estimate }\end{array}$ \\
\hline 1 & $.605^{\mathrm{a}}$ & .366 & .364 & 1.97311 \\
\hline
\end{tabular}

a. Predictors: (Constant), Physical Environment

The result in Table 3 depicts a coefficient (R square) of 0.366 . This implies that Physical environment accounts for $36.6 \%$ of the variations in return intention. The rest $63.4 \%$ can be explained by other factors not in the study.

Table 4 shows the ANOVA test done to test statistical significance between physical environment and return intention 
Table 4. ANOVA Test for physical environment and return intention

\begin{tabular}{clccccc}
\multicolumn{7}{c}{ ANOVA $^{\mathrm{a}}$} \\
\hline Model & & Sum of Squares & df & Mean Square & F & Sig. \\
\hline \multirow{2}{*}{1} & Regression & 770.627 & 1 & 770.627 & 197.944 & $.000^{\mathrm{b}}$ \\
& Residual & 1335.352 & 343 & 3.893 & & \\
& Total & 2105.979 & 344 & & & \\
\hline
\end{tabular}

a. Dependent Variable: Return Intention

b. Predictors: (Constant), Physical Environment

The results in Table 4 reveal that at a P- Value of 0.000 , there is a statistical significance between Physical environment and return intention at 0.05 confidence interval. This means that the physical environment statistically significantly predict the return intention. The regression model is therefore a good fit for the data.

Table 5. The regression analysis for physical environment and return intention

Coefficients $^{\mathrm{a}}$

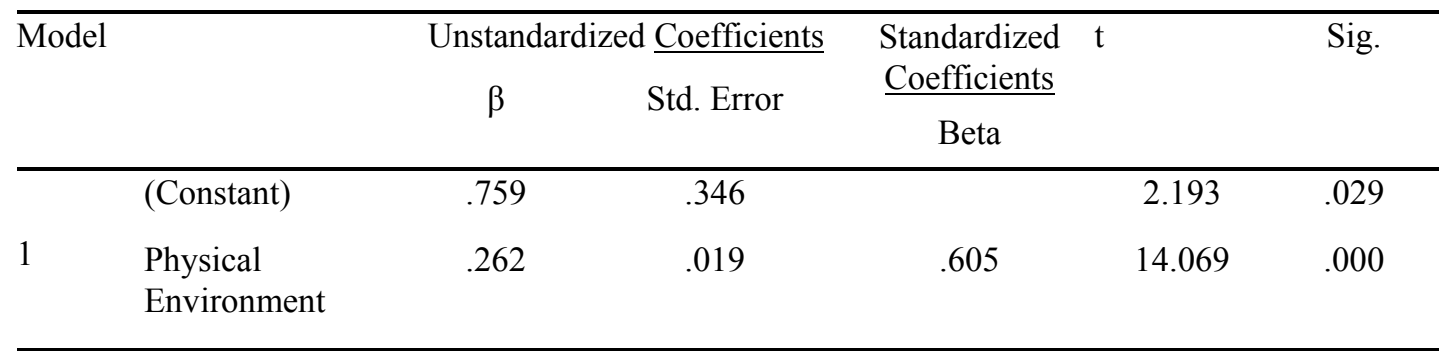

Dependent Variable: Return Intention

According to Table $5, \mathrm{Y}=0.759+0.262 \mathrm{X}_{1}$. A unit change in physical environment changes return intention at the rate of 0.262 . Table 5 shows a positive coefficient on $X_{1}\left(\beta_{1}=0.262\right)$ which means that physical environment has a positive effect on return intention. A p- value of 0.000 indicates that there is statistical significance between physical environment and return intention. Physical environment influence customers' return intention in Kenyan rated restaurants.

\section{Conclusion and Recommendations}

\subsection{Conclusion}

The respondents were dissatisfied (mode of 2) with the external environment and musical background. Pearson correlation coefficient and regression analysis showed that there was a positive correlation between physical environment and customers' return intention. These findings imply that when customers felt satisfied with physical environment, they were more likely to have higher return intention.Hence physical environment influenced customers return intention in rated restaurants. These results concur with the previous findings of Olise, Okoli and Ekeke (2015), Safian et al. (2013) and Dutta et al. (2014) who found that physical environment has a positive influence on customers' emotional responses which in turn led to revisit intention. The hypothesis was therefore retained.

\subsection{Recommendations}

The restaurant managers should study their customers and offer the background music suitable for their type of customers. Traditional dancers (matching with the cuisine served) may be introduced to entertain customers as they eat dinner. For instance African dancers for African cuisine. The restaurant managers should avoid monotony of music which would make the customers bored. The managers should also look for ways of improving external environment which is the first impression of the customers. For the city restaurants which have limited space, live plants can be planted on pots and arranged at the entrance of the restaurant. For the restaurants located off city center and have space, land scarping can be done and flowers planted to attract the customers. 


\section{Limitations and Further Research}

The results of this study are not without limitations. One main limitation of the study is that the selected sample size was 384 but 345 responses were collected from the respondents. This was as a result of the respondents handing over incomplete questionnaire or refusing to fill the questionnaire. Another limitation was that some of the documented rated restaurants had closed down thus reducing the targeted sample. Lastly, the results of this study cannot be generalized on unrated restaurants. Further research is recommended to incorporate the possible role of demographic differences, since customers reaction on physical environment may vary based on social demographic characteristics. The study also suggests that the same constructs be employed in examining customer satisfaction and return intention in rated hotels' dining room.

\section{Acknowledgements}

I wish to express my profound gratitude to National Commission for Science and Technology and Innovation (NACOSTI) of Kenya for granting me permission to carry out my study in Kenyan rated restaurants. Am also grateful to the managers, and customers of the rated restaurants in Nairobi and Coastal region of Kenya who assisted greatly giving the required information. Finally am thankful to Stephen Njunge who assisted me greatly in data collection.

\section{References}

Agresti, A., \& Finlay, B. (2009). Statistical methods for social sciences $\left(4^{\text {th }}\right.$ ed.) New Jersey, Person Education. Inc.

Bitner, M.J. (1990). Evaluating service encounters: the effects of physical surroundings and employee responses. Journal of Marketing, 54(2), 69- 82.

Chang, K. (2009). The impact of perceived physical environment on customers satisfaction and return intention. Journal of Professional services Marketing, 21(2), 75- 85.

Cohen, L.M. (2011). Research methods in Education. London: Rouledge Falmer.

Dutta, K., Parsa, H.G., Parsa, A.R., \& Bujistic, M. (2014). Change in customer patronage and willingness to pay at different levels of service attributes in restaurants: a study from India. Journal of Quality Assuarance in Hospitality and Tourism, 15(2), 149-174.

Fisher, A., Laing, J., Stoekel, E., \& Townsend, J. (1998). Handbook for Family Planning Operations Research Design ( $2^{\text {nd }}$ ed.). Population council. New York.

Geoff, N. (2010). "Likert" Scale Levels of measurement and the laws of statistics. Advances in Health Science Education. 15(5), 625-632.

Hair, J., Bush, R., \& Ortinar, D. (2002). Market research: Within a changing information on environment $\left(2^{\text {nd }}\right.$ ed.). McGraw- Hill Education.

Han, H., \& Ryu K. (2009). The roles of the physical environment, price perception, and customer satisfaction in determining customer loyalty in the restaurant industry. Journal of Hospitality Tourism, 33(4), 487-510. http://dxdoi.org/10.1177/1096348009344212

Jordaan, Y., \& Prinsloo, M. (2001). Grasping Service Marketing. Pretoria Grapevine News.

Kenya Gazette. $\left(2003,13^{\text {th }}\right.$ June). Gazette Notice No. 3976. The hotel and restaurant (Classification of hotels and restaurants), 1988 Classification. Vol CV-No.62, Nairobi.

Kim, W.G., \& Moon, Y.J. (2009). Customer cognitive emotional and actionable response to the service scope: a test of the moderating effect of the restaurant type. International Journal of Hospitality Management, 28, $144-156$.

Magnini, V.P., \& Parker, E.E. (2009). The psychological effect of music: implications for hotel firms. Journal of Vacation Marketing, 15(1), 53-62. http://dx.doi.org/10.1177/1356766708098171

Mombasa Restaurant Review. (2016). Retrieved $20^{\text {th }} \quad$ March 2016 from www.tripadvisor.com/Restaurant-g294210-Mombasa_coast_Province.html

Mugenda, O., \& Mugenda, A. (2003). Research Methods, quantitative and qualitative approaches (Revised Edition). African centre of technology studies press.

Nairobi Restaurant Review. (2016). Retrieved $20^{\text {th }} \quad$ March 2016 from www.tripadvisor.com/Restaurant-g294207-Nairobi.html 
Namasivayam, K., \& Mattila, A.S. (2007) Creating visible customer value. Cornell Hotel Restaurant Administration Quarterly, 31, 3-18.

Olise, M.C., Okoli, M.I., \& Ekeke, J.N. (2015).Factors influencing customers patronage of fast food restaurants. International Journal of Economics, Commerce and Management, 3(11), 686- 701.

Omar, M.S., Ariffin, H.F., \& Ahmed, R. (2015). The relationship between restaurant ambience and customer satisfaction in Sha Alam Arabic restaurant, Selangor. International Journal of Administration and Governance, 1(4), 1-8.

Ryu, K., \& Jang, S. (2008). DINESCAPE: A scale for customers' perception of dining environment. Journal of Food Service Business Research, 11(1), 2-22.

Sefian, M.N., Jiani, A., Sharudin, N.N., \& Abdulla, M.N. (2013). Determining factors that influence customer repatronage intention. A case study of Radix Fried Chicken in Malaysia. The $2^{\text {nd }}$ IBSM International conference on Business and Management, Chiang Mai- Bangkok, 2- 4 October 2013.

Tuzunkan, D., \& Albayrac, A. (2016). The importance of restaurant physical environment for Turkish customers. Journal of Tourism Research and Hospitality, 5, 1. http://dx.doi.org/10.4172/2324-8807.1000154

United Nations Environmental Programme. (2014). City of Nairobi environmental outlook report. Retrieved $1^{\text {st }}$ May 2015 from http://www.unep.org/geo/pdf/NCEO_Report_FF_Text.pdf

Wood, W.W., \& Allen, R. (2012). The rock 'n' roll classroom: Using music to manage mood, energy and learning. Thousand Oaks, CA: Corwin Press.

\section{Appendix}

\section{Questionnaire}

Section 1. (Social Demographic Profile)

Please indicate about yourself by putting a cross $(\mathbf{x})$ on the box of relevant answer
1. Gender:
(a) Male
(b) Female
2. Age group:
(a) 18- 25 years
(b) 26-35 years
(c) 36-45 years
(d) 46 years and above
3. Level of education:
(a) Primary
(b) Secondary
(c) Diploma
(d) Degree
(e) Other (specify).
4. Nationality:
(a) Kenyan (b) Non Kenyan (specify).
5. Monthly income:
(a) Less than 10,000 Ksh (Less than 98 USD)
(b) 10,000-20,000 Ksh (98-196 USD) (c) 20,001-30,000 Ksh (197- 294 USD)
(d) More than 30,000 Ksh (More than 294 USD)
7. Number of visits made in this restaurant
(a) First time
(b) Second time
(c) Third time

(d) Fourth time or more 
Section 2. Level of customer satisfaction in relation to physical environment

\begin{tabular}{lllllll}
\hline & $\begin{array}{l}\text { How satisfied were you } \\
\text { with each of these Physical } \\
\text { Environment dimensions }\end{array}$ & $\begin{array}{l}\text { Very } \\
\text { dissatisfied }\end{array}$ & Dissatisfied & Unsure & Satisfied & Very \\
& & 1 & 2 & 3 & 4 & 5 \\
\hline 1 & $\begin{array}{l}\text { External appearance of the } \\
\text { restaurant }\end{array}$ & & & & \\
\hline 2 & $\begin{array}{l}\text { Interior scheme of } \\
\text { restaurant }\end{array}$ \\
\hline 3 & $\begin{array}{l}\text { Temperature of the dining } \\
\text { area }\end{array}$ & & & & \\
\hline 4 & Music background & & & \\
\hline 5 & Lighting in the dining area & & & \\
\hline 6 & Type of linen & & \\
\hline 7 & $\begin{array}{l}\text { Type of furnishing (seats, } \\
\text { tables, carpets etc) }\end{array}$ & & \\
\hline 8 & $\begin{array}{l}\text { Signs to the smoking zone } \\
\text { area }\end{array}$ & & \\
\hline 9 & $\begin{array}{l}\text { Arrangements of chairs and } \\
\text { tables }\end{array}$ & \\
\hline
\end{tabular}

\section{Copyrights}

Copyright for this article is retained by the author(s), with first publication rights granted to the journal.

This is an open-access article distributed under the terms and conditions of the Creative Commons Attribution license (http://creativecommons.org/licenses/by/4.0/). 